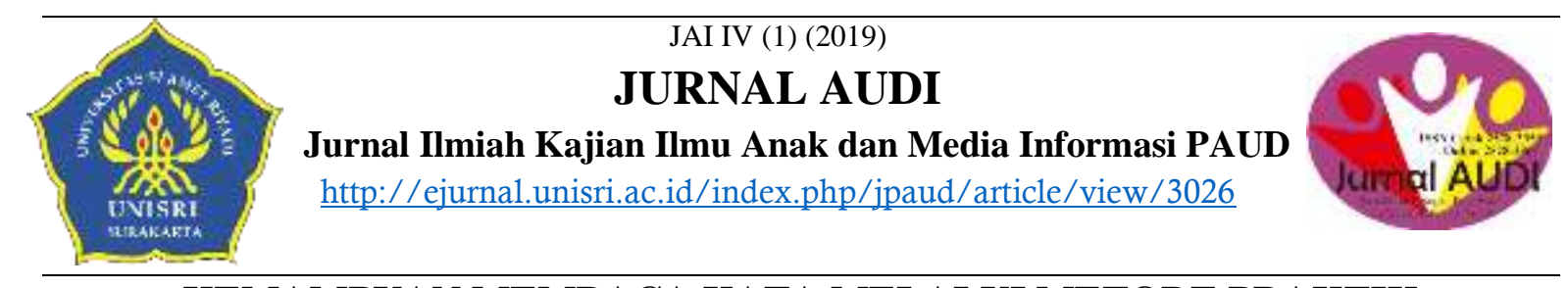

\title{
KEMAMPUAN MEMBACA KATA MELALUI METODE PRAKTIK LANGSUNG DENGAN KARTU HURUF
}

\author{
Suratiyah \\ Taman Kanak-Kanak Dharma Wanita II Mergowati
}

\section{Info Artikel}

Sejarah Artikel:

Diterima Januari 2019

Disetujui April 2019

Dipublikasikan Juni

2019

\section{Keywords:}

read words, direct

practice, letter cards

\begin{abstract}
Abstrak
Tujuan dari penelitian ini adalah mengetahui metode praktik langsung dengan kartu huruf dapat meningkatkan kemampuan membaca kata anak dan mengetahui besarnya peningkatan kemampuan membaca kata melalui metode praktik langsung dengan kartu huruf pada anak Kelompok B TK Dharma Wanita II Mergowati Kecamatan Kedu Kabupaten Temanggung Semester II Tahun Ajaran 2017/2018. Subyek penelitian ini adalah peserta didik Kelompok B TK Dharma Wanita II Mergowati berjumlah 20 anak. Penelitian dilakukan bulan Maret sampai dengan April 2018. Metode pengumpulan data adalah observasi, dokumentasi dan wawancara. Kesimpulan penelitian ini adalah melalui praktik langsung dengan media kartu huruf dapat meningkatkan kemampuan membaca kata anak. Hal ini dibuktikan dengan adanya peningkatan kemampuan membaca permulaan anak sebelum tindakan hanya mencapai $10 \%$, kemudian setelah diadakan perbaikan pada Siklus I meningkat menjadi $45 \%$, dan Siklus II menjadi $85 \%$, telah memenuhi persentase maksimum yang telah ditentukan yaitu $80 \%$. Keberhasilan ini ditandai dengan anak mampu menyebutkan simbol huruf yang melambangkan, anak mampu menyusun huruf menjadi sebuah kata yang bermakna, anak mampu menyebutkan kelompok gambar yang memiliki bunyi / huruf awal/akhir yang sama, anak mampu membaca dan menulis kata sederhana.
\end{abstract}

\begin{abstract}
The purpose of this study is: Knowing the direct practice method with letter cards can improve the child's reading skills and find out the magnitude of the increase in the ability to read words through direct practice methods with letter cards in children. 2017/2018. The subjects of this study were 20 students in the B Group of Dharma Wanita II Mergowati Kindergarten. The study was conducted from March to April 2018. Methods of data collection were observation, documentation, and interviews. The conclusion of this study is that through direct practice with a letter card media can improve children's reading skills. This is evidenced by the increase in the ability to read the beginning of the child before the action only reached $10 \%$, then after the improvement in Cycle I increased to $45 \%$, and Cycle II to $85 \%$, has met the maximum percentage that has been determined that is $80 \%$. This success is indicated by the child being able to mention symbol letters symbolizing, the child is able to arrange letters into a meaningful word, the child is able to mention groups of images that have the same initial / final sound/letter the child is able to read and write simple words.
\end{abstract}

(C) 2019 FKIP Universitas Slamet Riyadi

\begin{tabular}{lr}
\hline Alamat korespondensi: Dusun Ngebrak Desa & ISSN 2528-3359 (Print) \\
Mergowati Kecamatan Kedu Kabupaten Temanggung & ISSN 2528-3367(Online)
\end{tabular}

E-mail: suratiyah001@gmail.com 


\section{PENDAHULUAN}

Kemampuan bahasa anak merupakan kemampuan yang sangat penting untuk distimulasi sejak dini, yaitu sejak usia prasekolah yang selanjutnya akan memberikan keterampilan kepada anak untuk dapat berbahasa dan berkomunikasi dengan baik dan benar kepada semua orang. Dengan anak dapat menggunakan bahasa, maka anak akan tumbuh dan berkembang seperti anak pada umumnya dan menjadi manusia dewasa yang dapat berkomunikasi dengan lingkungan masyarakat. Menurut Rakimahwati, dkk (2018: 2) menjelaskan" Kemampuan membaca anak usia Taman Kanak-kanak adalah kemampuan anak dalam mengubah simbol huruf ke dalam pengucapan atau lisan, kemampuan mengaitkan apa yang telah diucapkan anak dengan simbolnya dalam bentuk huruf. Anak-anak yang gemar membaca akan mempunyai rasa kebahasaan yang lebih tinggi. Montessori dan Hainstock (2002:103) "mengemukakan bahwa pada usia 4-5 tahun anak sudah bisa diajarkan membaca. Bahkan membaca merupakan permainan yang menyenangkan bagi anak usia ini”. Menurut Resti (2012:347) Memahami bacaaan berarti memahami makna-makana yang terkandung dari wavana yang telah dibaca. Dengan dibiasakannya belajar membaca sejak dini, maka anak akan memperoleh informasi yang lebih banyak dari apa yang telah dibacanya".

Hasil observasi yang dilaksanakan peneliti di Taman Kanak-kanak Dharma Wanita II Mergowati pada kelompok B terdapat 20 anak yang terdiri dari 13 anak laki-laki dan 7 anak perempuan. Peneliti menemukan berbagai permasalahan yang terjadi yaitu anak belum mampu membaca kata yang ditunjukkan oleh guru, hal ini terlihat ketika salah satu anak diminta untuk menyebutkan atau membaca kata, anak-anak hanya bisa menyebutkan kurang dari sepuluh kata sesuai dengan tema. Dalam pembelajaran guru masih menggunakan teknik menirukan secara lisan dengan tidak menggunakan media sehingga anakanak kurang mengingat kata-kata yang telah disampaikan dan pembelajaran yang kurang menarik membuat anak cepat bosan.

Permasalahan-permasalahan tersebut di atas menunjukkan bahwa kualitas kemampuan bahasa aspek membaca kata pada anak kelompok B Taman Kanak-kanak Dharma Wanita II Mergowati Kecamatan Kedu Kabupaten Temanggung perlu ditingkatkan. Kemampuan bahasa aspek membaca kata pada anak dapat ditingkatkan dengan mudah apabila media pembelajaran yang digunakan mudah diingat anak dan tentunya menarik untuk anak sehingga anak tidak cepat bosan dalam mengikuti proses pembelajaran. Salah satu cara untuk meningkatkan kemampuan membaca kata adalah melalui praktik langsung dengan media kartu huruf. Metode ini akan mempermudah anak mengingat kata yang sedang dipelajari dan tentunya menarik bagi anak sehingga mereka tidak cepat bosan.

Berdasarkan permasalahan di atas, peneliti bermaksud mengadakan penelitian tindakan kelas yang berjudul "Upaya Meningkatkan Kemampuan Membaca Kata Melalui Metode Praktik Langsung dengan Kartu Huruf pada Anak Kelompok B 
TK Dharma Wanita II Mergowati Kecamatan Kedu Kabupaten Temanggung Semester II Tahun Ajaran 2017/2018". Dengan melakukan penelitian ini diharapkan dapat mengatasi masalah rendahnya kemampuan membaca kata pada anak dan dapat memberikan kontribusi pada anak didik sehingga meningkatkan kompetensinya.

Berdasarkan latar belakang di atas, maka dapat diidentifikasi permasalahan sebagai berikut:

1. Kurangnya pemahaman anak tentang kata.

2. Kurangnya penguasaan membaca kata pada anak.

3. Masih banyak anak yang kurang aktif mengikuti pembejaran di kelas.

4. Dalam pembelajaran guru kurang menggunakan media yang inovatif.

5. Metode mengajar guru terkesan monoton sehingga kurang memotivasi anak didik dalam kegiatan pembelajaran.

\section{KAJIAN PUSTAKA}

\section{Kemampuan Membaca Permulaan} Utami munandar (1999:17) " mengemukakan kemampuan adalah daya untuk melakukan tindakan sebagai hasil dari pembawaan latihan". Kemampuan membaca juga bisa disebut hasil belajar. Gagne dan Briggs (1999:49-54) “ Menjelaskan kemampuan hasil belajar terdiri dari (1) kemahiran intelektual (intelectual skills), (2) strategi kognitifcognitive strategies), (3) informasi verbal (verbal information), (4) ketrampilan motorik (motor-skill), dan (4) sikap (attitude).

Ruddell dalam choirun Nisak (2012:134) "membaca sebagai salah satu dari penggunaan berbahasa untuk menguraikan tulisan atau simbol dan memahaminya". Sependapat dengan Hadini (2017) yang mengatakan "kemampuan membaca merupakan kegiatan menelusuri, memahami, hingga mengeksplorasi berbagai simbol. Simbol dapat berupa rangkaian huruf-huruf dalam suatu tulisan atau bacaan bahkan gambar". Disempurnakan juga dengan Dardjowidjojo (2003: 301) menyebutkan"membaca hanya dapat dilakukan ketika anak sudah memenuhi prasyarat tertentu untuk berbicara. Sementara Grainger (2003: 185) menjelaskan" kesiapan untuk memulai pengajaran membaca tergantung pada kesadaran fonemis dan Proses membaca mewajibkan pembaca menggunakan ketrampilan diskriminasi visual dan suara, proses perhatian, dan memori ". Mayer dan Sims (1994: 390) menambahkan "Proses diskriminasi visual dan suara tersebut dapat dijelaskan menggunakan teori pengkodean ganda (dual coding theory). Kemampuan membaca juga sangat sesuai jika dilakukan dengan metode praktek langsung. Hal ini diperkuat pendapat dari Nur Chasanah dan Anik S.( yang mengatakan "Metode pembelajaran praktek lapangan merupakan metode pembelajaran yang dilakukan dengan tujuan untuk melatih dan meningkatkan kemampuan peserta dalam engaplikasikan pengetahuan dan keterampilan yang diperolehnya.

\section{Penggunaan Kartu Huruf}

I Gusti Ayu,. dkk (2014:4) menjelaskan" Kartu huruf adalah salah satu media pembelajaran yang berupa potonganpotongan kartu yang berbentuk persegi panjang yang bertuliskan suatu simbol atau huruf setiap kartu dan merupakan alat bantu anak dalam belajar membaca". Menurut Nurul A dan Sri Setyowati (2014) "Kartu huruf adalah gambar huruf yang dituangkan pada selembar karton 
berbentuk kartu yang cukup besar. Kartukartu tersebut memuat huruf yang ditulis dengan huruf kecil anak hanya mengamati huruf-huruf yang tertuang pada kartu". Menurut Soeparno dalam D. Prasetiani, and L. Diner (2014:17) mengatakan" media kartu huruf termasuk dalam jenis media pandang nonproyeksi.

\section{METODE}

Penelitian ini adalah penelitian tindakan kelas (PTK) yang didalamnya ada tahapan siklus yang setiap siklusnya meliputi planning (rencana), action (tindakan), observation (pengamatan), dan reflection (refleksi). Subyek penelitian merupakan peserta didik yang dikenai tindakan yaitu semua anak kelompok B usia 5-6 tahun yang berjumlah 20 anak yang terdiri dari 13 anak laki-laki dan 7 anak perempuan dengan melibatkan 1 orang guru sebagai observer.

Teknik pengumpulan data dengan cara observasi, wawancara dan dokumentasi Langkah-langkah analisa data :

1. Memberikan nilai pada setiap hasil pengamatan.

2. Membuat tabulasi nilai observasi kemampuan anak melalui metode praktik langsung dengan kartu kata yang terdiri dari no, nama, butir pengamatan, skor, persentase.

3. Menjumlahkan skor yang dicapai anak pada setiap butir pengamatan.

4. Menghitung persentase pencapaian peningkatan kemampuan setiap anak dengan cara :

Jumlah skor butir pengamatan $\underline{\text { anak }}$ Skor maksimum x $100 \%$

5. Menghitung hasil rata-rata pencapaian dengan skor maksimum pada setiap siklus yang telah ditentukan.

6. Membandingkan hasil persentase pencapaian pada setiap anak dengan persentase keberhasilan pada setiap siklus yang telah ditentukan

\section{HASIL}

\section{Diskripsi Kondisi Awal}

Pembelajaran aspek perkembangan bahasa khususnya tentang membaca kata pada prasiklus dari 20 peserta anak didik, hanya $2(10 \%)$ anak yang menunjukkan kemampuannya berkembang sesuai harapan, $3(15 \%)$ mulai berkembang, 15 (75\%) anak belum berkembang.

Tabel 1 Kondisi Pra Siklus

\begin{tabular}{ccc}
\hline Penilaian & Jumlah Anak & Persentase \\
\hline BB & 15 & $75 \%$ \\
MB & 3 & $15 \%$ \\
BSH & 2 & $10 \%$ \\
BSB & 0 & $0 \%$ \\
\hline
\end{tabular}

Berdasarkan tabel dan grafik di atas dapat disimpulkan bahwa kemampuan membaca kata anak kelompok B TK Dharma Wanita II Mergowati masih rendah. Padahal yang diharapkan dalam kegiatan tersebut $80 \%$ anak berhasil atau anak mampu menunjukkan kemampuan membaca kata dengan baik.

\section{Siklus I}

Hasil pengamatan pertemuan pertama Siklus I didapat data 5 anak (25\%) dengan penilaian berkembang sesuai harapan, 4 anak (20\%) mulai berkembang, dan 11 anak (55\%) belum berkembang. Terjadi peningkatan dari keadaaan pra siklus. Hasil analisis observasi terhadap peningkatan kemampuan membaca kata anak pada Siklus I pertemuan kedua adalah 9 anak (45\%) dengan penilaian berkembang sesuai harapan, 
4 anak (20\%) mulai berkembang, 7 anak (35\%) belum berkembang dan masih memerlukan bimbingan.

Tabel 2. Peningkatan Kemampuan

\begin{tabular}{|c|c|c|c|c|}
\hline \multirow[b]{2}{*}{$\begin{array}{r}\text { Penila } \\
\text { ia } \\
\text { n }\end{array}$} & \multicolumn{2}{|c|}{ Pertemuan I } & \multicolumn{2}{|c|}{ Pertemuan II } \\
\hline & $\begin{array}{c}\text { Jumla } \\
\text { anak }\end{array}$ & $\%$ & $\begin{array}{c}\text { Jumlah } \\
\text { anak }\end{array}$ & $\%$ \\
\hline BB & 11 & $55 \%$ & 7 & $35 \%$ \\
\hline MB & 4 & $20 \%$ & 4 & $20 \%$ \\
\hline BSH & 5 & $25 \%$ & 9 & $45 \%$ \\
\hline BSB & 0 & $0 \%$ & 0 & $0 \%$ \\
\hline
\end{tabular}

Dari hasil tersebut menunjukkan adanya peningkatan jumlah anak yang tuntas walaupun hasilnya belum optimal, pada pertemuan pertama tercatat hanya $25 \%$ anak yang mendapatkan penilaian berkembang sesuai harapan meningkat menjadi $45 \%$ pada pertemuan kedua Siklus I.

\section{Siklus II}

Hasil pengamatan pada pertemuan pertama Siklus II didapatkan data bahwa 4 anak (20\%) dengan penilaian belum berkembang, 4 anak (20\%) mulai berkembang, dan 12 anak (60\%) berkembang sesuai harapan. Hasil observasi pertemuan pertama, peningkatan kemampuan membaca kata anak pada Siklus I ada 9 anak menunjukkan persentase $45 \%$ meningkat menjadi 12 anak atau $60 \%$ anak berkembang sesuai harapan.

Tabel 3 Meningkatan Kemampuan

\begin{tabular}{ccccc}
\multicolumn{4}{c}{ Membaca Kata Anak Siklus II } \\
\hline \multirow{2}{*}{ Penilaian } & \multicolumn{2}{c}{ Pertemuan I } & Pertemuan \\
\cline { 2 - 5 } & $\begin{array}{c}\text { Jumlah } \\
\text { anak }\end{array}$ & $\%$ & $\begin{array}{c}\text { Jumlah } \\
\text { anak }\end{array}$ \\
\hline BB & 4 & $20 \%$ & 2 & $10 \%$ \\
\hline MB & 4 & $20 \%$ & 1 & \\
\hline BSH & 12 & $60 \%$ & 17 & $85 \%$ \\
\hline BSB & 0 & $0 \%$ & 0 & \\
\hline
\end{tabular}

\begin{abstract}
Dari hasil tersebut menunjukkan adanya peningkatan jumlah anak yang tuntas, 17 anak atau $85 \%$ anak sudah mampu menunjukkan kemampuannya membaca kata dengan kategori berkembang sesuai harapan, 1 anak atau 5\% mulai berkembang, dan 2 anak atau $10 \%$ belum berkembang.
\end{abstract}

\section{PEMBAHASAN}

Hasil dari tindakan tersebut dapat dilihat bahwa peningkatan kemampuan membaca kata anak pada setiap siklus tidak menunjukkan suatu kestabilan, di mana persentase peningkatan siklus I mencapai $45 \%$ dan siklus II mencapai $85 \%$. Hal ini menunjukkan bahwa tindakan sampai Sikus II mengalami meningkatan yang signifikan, sehingga hal ini membuktikan hipotesis tindakan yaitu melalui metode praktik langsung dengan kartu huruf dapat meningkatkan kemampuan membaca kata anak Kelompok B TK Dharma Wanita II Mergowati Kecamatan Kedu Kabupaten Temanggung Semester II Tahun Pelajaran 2017/2018 lebih dari $80 \%$.

Implementasi dari metode praktik langsung dengan kartu huruf yaitu terlebih dahulu peneliti memberikan penjelasan tentang metode praktik langsung dan memperkenalkan alat yang digunakan yaitu kartu huruf. Kemudian peneliti memberikan contoh kepada anakanak cara bermain kartu huruf yang benar. Peneliti memberi kesempatan kepada anak untuk $\%$ mempraktikkannya di depan kelas, memberikan motivasi, dan reward 10\%kepada anak yang berhasil $5 \%$ menyelesaikan tugasnya dengan baik. $85 \%$ Tindakan pada penelitian ini 0\%dilakukan melalui metode praktik langsung dengan kartu huruf untuk 
meningkatkan kemampuan membaca kata anak. Hasil penelitian ini sesuai dengan teori yang dikemukakan Djamarah dan Zain (2002: 95), praktik langsung adalah proses pembelajaran di mana anak didik melakukan dan mengalami sendiri, mengikuti proses, mengamati, menganalisis, membuktikan, dan menarik kesimpulan dari materi yang dipelajari.

Setelah dilakukan analisa data, maka pengujian hipotesis menyimpulkan bahwa melalui metode praktik langsung dengan kartu huruf dapat meningkatkan kemampuan membaca kata anak Kelompok B TK Dharma Wanita II Kecamatan Kedu Kabupaten Temanggung Semester II Tahun Pelajaran 2017/2018, hal ini ditunjukkan dengan adanya peningkatan yang signifikan pada kemampuan membaca kata anak. Peningkatan persentase kemampuan anak pada pratindakan sebesar $10 \%$ mengalami peningkatan pada Siklus I sebesar $45 \%$, sedangkan pada Siklus II mengalami peningkatan sebesar $85 \%$ dengan kriteria berkembang baik dan telah mencapai indikator keberhasilan yaitu $80 \%$. Anak telah mampu memenuhi indikator keberhasilan yang diharapkan yaitu anak telah mampu menyebutkan simbol huruf yang melambangkannya, anak mampu menyusun kartu huruf menjadi sebuah kata yang bermakna, anak mampu menyebutkan kelompok gambar yang memiliki bunyi/ huruf awal/akhir yang sama, anak mampu membaca dan menulis kata sederhana.

\section{SIMPULAN}

1) Melalui metode praktik langsung dengan kartu huruf kemampuan membaca kata anak Kelompok B TK Dharma Wanita II Mergowati dapat berkembang. Hal ini dapat dibuktikan dengan adanya peningkatan kemampuan membaca kata anak dari sebelum tindakan pada pra siklus hanya $10 \%$, Siklus I mencapai $45 \%$ dan Siklus II mencapai $85 \%$. Maka dari itu upaya peningkatan kemampuan membaca kata anak Kelompok B TK Dharma Wanita II Mergowati dapat dikatakan berhasil karena telah memenuhi persentase maksimum yang telah ditentukan yaitu $80 \%$.

2) Metode praktik langsung dengan kartu huruf terbukti efektif dapat meningkatkan kemampuan membaca kata anak di Kelompok B TK Dharma Wanita II Mergowati Kecamatan Kedu Kabupaten Temanggung Semester II Tahun Pelajaran 2017/2018.

\section{DAFTAR RUJUKAN}

Chasanah, N., \& Supriani, A. (2016). Penerapan Metode Praktik untuk Meningkatkan Kemampuan Melaksanakan Promosi Kesehatan. Jurnal Ilmiah Keperawatan (Scientific Journal of Nursing), 2(1), 1-5.

Aulina, C. N. (2012). Pengaruh Permainan dan Penguasaan Kosakata Terhadap Kemampuan Membaca Permulaan Anak Usia 5-6 Tahun. PEDAGOGIA: Jurnal Pendidikan, 1(2), 131-144.

Dardjowidjojo, S. 2003 Psikolinguistik: Pengantar Pemahaman Bahasa Manusia. Jakarta: Yayasan Obor Indonesia. 
Prasetiani, D., \& Diner, L. (2014).

Meningkatkan Kemampuan

Kanji Mahasiswa Melalui

Media Kartu Huruf

Kanji. Izumi, 3(2), 15-21.

Grainger, J. 2003. Problem Perilaku,

Perhatian, dan Membaca pada

Anak:Strategi Intervensi

Berbasis Sekolah (Alih Bahasa:

Enny Irawati). Jakarta:

Grasindo.

Hadini,

$\mathrm{N}$.

(2017).

MENINGKATKAN

KEMAMPUAN MEMBACA

ANAK USIA DINI MELALUI

KEGIATAN PERMAINAN

KARTU KATA DI TK AL-

FAUZAN

DESA

CIHARASHAS

KECAMATAN CILAKU

KABUPATEN

CIANJUR. Empowerment, 6(1)

Hainstock, E. G. 2002. Montessori untuk Anak Prasekolah. Jakarta:Pustaka Delaprasta.

PADMI, I. G. A., Dantes, N., \& Sutama, I. M. (2014). Efektivitas Implementasi Metode Bermain Berbantuan Media Kartu Huruf Untuk Meningkatkan Kemampuan Membaca Gambar Dan Sosial Emosional Anak. PENDASI: Jurnal Pendidikan Dasar Indonesia, 4(1).

Mayer, R. E., \& Sims, V. K. (1994). For whom is a picture worth a thousand words? Extensions of a dual-coding theory of multimedia learning. Journal of educational psychology, 86(3), 389.

Setyowati, S. (2014). Pengaruh Penerapan Media Kartu Huruf Warna-Warni Terhadap Kemampuan Membaca Awal Anak Kelompok B di TK Islam Hubbul Wathon Kedunganyar Wringinanom Gresik. PAUD Teratai, 3(3).

Rakimahwati, R. (2018). Pelatihan Pembuatan Boneka Jari Bergambar dalam Meningkatkan Kemampuan Membaca Anak Usia Dini Di Kecamatan V Koto Kampung dalam Kabupaten Padang Pariaman. Early Childhood: Jurnal Pendidikan, 2(2b), 1-11. Aulia, R. (2012). Meningkatkan Kemampuan Membaca Pemahaman pada Anak. Tunarungu. Jurnal Ilmiah Pendidikan Khusus, 1.

Robert M. Gagne and Leslie J. Briggs, Principle of Instructional Design (New York: Richard and Winston, 1999).

Syaiful Bahri Djamarah dan Aswan Zain. 2002. Strategi Belajar Mengajar, Jakarta: Rineka Cipta.

Utami Munandar, Mengembangkan Bakat dan Kreativitas Anak Sekolah (Jakarta: PT Gramedia, 1999). 